Acta vet. scand. $1969,10,255-274$.

From The National Veterinary Institute, The Royal Veterinary College, and The National Bacteriological Laboratory, Stockholm, Sweden.

\title{
STUDIES ON ASPERGILLUS FUMIGATUS; HYDROLYSIS OF POLYAMINO ACIDS BY MYCELIAL FILTRATE AND CHROMATO- GRAPHIC FRACTIONATION OF THE FILTRATE
}

\author{
By \\ Lars Rutqvist and Gunnar Lundblad
}

The properties of intracellular proteinase from Aspergillus fumigatus (AF) have been described in a previous paper (Rutquist $1969 \mathrm{~b}$ ).

In the present work, the ability of mycelial filtrate from AF to hydrolyze poly-L-lysine and poly-L-glutamine at various $\mathrm{pH}$ values has been investigated by means of a viscosimetric method that was initially worked out by Hultin (Hultin 1946, 1948, Hultin \& Lundblad 1955, Lundblad \& Hultin 1966, Hultin \& Wanntorp 1966) and was later applied by Söder (1967) in his studies of poly- $\alpha$-amino acid hydrolysis caused by proteinase in dental plaque material. The hydrolysis of polyglutamine at optimum pH was also investigated spectrophotometrically following gel filtration.

It has been shown earlier (Rutqvist 1965, 1968, 1969 a) that mycelial filtrate from AF possesses haemolytic, toxic and casein precipitating properties. It has also been shown that the proteolytic activity of dialyzed filtrate has 3 activity optima at different $\mathrm{pH}$ values (Rutqvist $1969 \mathrm{~b}$ ). To illustrate the mutual relations of these activity optima and their relations to casein precipitating enzyme, haemolysin and toxin, mycelial filtrate has been fractionated by means of gel filtration. In addition, purified proteinase-positive fractions have been studied from an immunochemical point of view. 


\section{MATERIALS AND METHODS}

Strain. The strain used in these experiments was the AF strain 6869 from the AF collection previously described (Rutqvist 1965).

Media. The strain has been cultivated at room temperature on Sabouraud agar slants, with transfers made once a month. A culture for producing mycelial filtrate has been grown in a liquid medium, comprising proteose-peptone Difco $(1.5 \%)$, yeast extract Difco $(0.5 \%)$, dextrose $(3 \%)$, and $\mathrm{NaCl}(0.5 \%)$ in distilled water, $\mathrm{pH} 7.2$.

Filtrate preparation. A stock culture grown for 7 days on Sabouraud agar slants was suspended in $10 \mathrm{ml}$ of liquid culture medium for each test tube, $1 \mathrm{ml}$ of the resultant suspension then being transferred to $300 \mathrm{ml}$ liquid medium in Roux flasks. At the harvest, the mycelial growths present on the surface of the medium after 3 days' incubation at $37^{\circ} \mathrm{C}$ were washed with sterile distilled water, dried between filter papers, and stored at $-20^{\circ} \mathrm{C}$ during $2-4$ days.

$100 \mathrm{~g}$ of the frozen mycelial material and $75 \mathrm{ml}$ sterile distilled water were mixed, the mixture being homogenized for $20 \mathrm{~min}$. in a mixer running at 11,000 r.p.m. The supernatant liquid was subsequently centrifuged at $2,500 \times \mathrm{g}$ and filtered through a Seitz EK filter. The filtrate ( $\mathrm{pH}$ 6.7) was then stored at $-20^{\circ *}$ ).

Antiserum. Antiserum against mycelial filtrate from AF strain 6869 was prepared as described by Rutqvist (1969 a). On 4 occasions at 1 -week intervals rabbits were injected intramuscularly $2,3,4$, and $5 \mathrm{ml}$, respectively, of a mixture of equal parts formalin-treated fil. trate and Difco Bacto adjuvant complete. Two weeks later, series of $0.5,0.6,0.7,0.8$, and $1 \mathrm{ml}$ formalin-treated filtrate were injected intravenously, and the immunization was completed by 4 intravenous injections of $0.01,0.1,0.2$, and $0.5 \mathrm{ml}$, respectively, of untreated filtrate, corresponding to $4-200 \mathrm{MLD}_{50}$ of toxin. The intravenous injections were made at 3-4 days' intervals. Serum was collected 14 days after the last injection. After heating the serum at $56^{\circ} \mathrm{C}$ for 30 min., merthiolate to $0.01 \%(\mathrm{w} / \mathrm{v})$ was added. The serum was then stored at $4^{\circ} \mathrm{C}$.

\section{Fractionation of mycelial filtrate}

The mycelial filtrate was fractionated on a chromatographic column using either of Sephadex G-75 and Sephadex G-100 (the Sephadex gel used in these experiments was manufactured by $\mathrm{AB}$ Pharmacia Fine Chemicals, Uppsala, Sweden). Portions of the Sephadex gel were treated according to the maker's instructions and filled into columns that were buffered with $0.2 \mathrm{M}$ acetate buffer ( $\mathrm{pH}$ 5.2), containing $1.5 \%(\mathrm{v} / \mathrm{v})$ butanol. This buffer solution was also used as an elution agent. The gel filtration was carried out at $5^{\circ} \mathrm{C}$.

*) The filtrate titres for toxic activity measured as $\mathrm{LD}_{50}$ for mice $\left(\mathrm{MLD}_{50}\right)$ and haemolytic activity (HU) were $10^{-2.6} \mathrm{ml}$ and $2^{-10} \mathrm{ml}$, respectively. The determinations of $\mathrm{MLD}_{50}$ and $\mathrm{HU}$ were made according to descriptions published previously (Rutqvist 1968). 
The Sephadex G-75 column, measuring $2.8 \times 172 \mathrm{~cm}$, was charged with $8 \mathrm{ml}$ mycelial filtrate that had been concentrated from $100 \mathrm{ml}$ to $20 \mathrm{ml}$ by Sephadex G-25 Coarse. An addition of sucrose to a concentration of $5 \%$ was made to the concentrated filtrate in order to increase its density before it was entered into the column. The flow rate was $22-25 \mathrm{ml} / \mathrm{hr}$., the effluent being collected in 5-ml fractions.

The Sephadex G-100 column, measuring $5.2 \times 172 \mathrm{~cm}$, was charged with $40 \mathrm{ml}$ mycelial filtrate containing $5 \%$ sucrose. The flow rate dropped gradually from an initial $45 \mathrm{ml} / \mathrm{hr}$. to a final $25 \mathrm{ml} / \mathrm{hr}$. The effluent was collected in $10-\mathrm{ml}$ fractions.

In both cases the mycelial filtrate was poured on top of the Sephadex gel, between the gel surface and the covering buffer solution, using a special syringe.

The optical density of each fraction was determined on a type DU Beckman spectrophotometer at 260 and $280 \mathrm{~m} \mu$ and the fractions were stored at $-20^{\circ} \mathrm{C}$ until activity determinations could be performed.

\section{Concentration of mycelial filtrate}

Twenty g Sephadex G-25 Coarse was added to $100 \mathrm{ml}$ of the crude filtrate and the mixture was left at $4^{\circ} \mathrm{C}$ overnight. Centrifugation at $5,000 \times \mathrm{g}$ yielded $20 \mathrm{ml}$ concentrated filtrate. The titre for haemolytic activity ( $\mathrm{HU}$; cf. footnote on p. 256) showed an increase from $2^{-10} \mathrm{ml}$ in the crude filtrate to $2^{-13} \mathrm{ml}$ in the concentrate.

\section{Determination of proteolytic activity}

(A) Hydrolysis of poly- $\alpha$-amino acids. The ability of filtrate from AF mycelium to break down poly-L-lysine, $\mathrm{HBr}$, mol.wt. 90,000, and poly-L-glutamic acid, $\mathrm{Na}$ salt, mol.wt. 75,000 (both compounds from Pilot Chemicals Inc., Watertown, Mass., USA), was determined by a viscosimetric process devised by Hultin (1946). The reaction mixture, comprising $0.5 \mathrm{ml}$ crude filtrate, $1 \mathrm{ml}$ buffer solution ( $0.2 \mathrm{M}$ McIlvaine and $0.2 \mathrm{M}$ glycine buffer, respectively) and $1 \mathrm{ml} 4 \%(\mathrm{w} / \mathrm{v})$ polyamino acid in distilled water, was incubated at $35.5^{\circ} \mathrm{C}$. The determinations were performed in an Ostwald viscosimeter at $35.5^{\circ} \mathrm{C}$ and the enzymatic activity of the filtrate was then calculated in accordance with the formula given by Hultin (cf. Lundblad \& Johansson 1968), viz.

$$
\mathrm{A}=\frac{\mathrm{a}+\mathbf{b}}{\mathrm{a}} \times \mathrm{Cs}_{\mathbf{s}^{2}} \times \frac{\mathrm{d}\left(\frac{1}{\eta_{\mathrm{sp}}}\right)}{\mathrm{dt}}=\frac{\mathrm{a}+\mathbf{b}}{\mathrm{a}} \times \mathrm{C}_{\mathbf{s}^{2}} \times \alpha
$$

in which $\mathrm{a}=$ filtrate $(\mathrm{ml})$

$\mathrm{b}=$ liquid medium $(\mathrm{ml})$

$\mathrm{C}_{\mathrm{s}}=$ concentration of medium in reaction mixture ( $\mathrm{g}$ medium per g solution)

$\eta_{\text {sp }}=$ specific viscosity

$\mathrm{t}=$ time (sec.) 
and hence

$$
\begin{aligned}
& \alpha=\begin{array}{l}
\text { inclination of line obtained by plotting } \frac{1}{\eta_{\text {sp }}} \\
\text { against time. }
\end{array} \\
& \eta_{\text {sp }}=\frac{\text { efflux time of mixture }- \text { efflux time of water }}{\text { efflux time of water }}= \\
& =\frac{{ }^{\tau} \mathrm{mix}-\tau{ }^{\tau} \mathrm{H}_{2} \mathrm{O}}{{ }^{\tau} \mathrm{H}_{2} \mathrm{O}}
\end{aligned}
$$

$$
\frac{1}{\eta_{\mathrm{sp}}}=\frac{{ }^{\tau} \mathrm{H}_{2} \mathrm{O}}{\tau_{\mathrm{mix}}-\tau_{\mathrm{H}_{2} \mathrm{O}}}
$$

The activity values (A) thus obtained were multiplied by $10^{9}$ and were denominated "Hultin units" (H.U.) as suggested by Lundblad (1962).

The degradation of poly-L-glutamine at $\mathrm{pH} 5$ was also followed spectrophotometrically. To this end we incubated a reaction mixture comprising $2 \mathrm{ml} 4 \%$ (w/v) poly-L-glutamine, $2.70 \mathrm{ml} 0.2 \mathrm{M}$ McIlvaine buffer $(\mathrm{pH} 5.0)$, and $1.30 \mathrm{ml}$ of filtrate that was dialyzed against $0.02 \mathrm{M}$ phosphate buffer $(\mathrm{pH} 6.8)$ at low temperature for $20 \mathrm{hrs}$. During dialysis the dialyzing medium was changed several times. One-ml samples of the reaction mixture were withdrawn after 0,2 , 4 , and $6 \mathrm{hrs}$. incubation at $35.5^{\circ} \mathrm{C}$ in a shaker incubator and gel filtrated on a Sephadex G-25 Fine column measuring $1.1 \times 163 \mathrm{~cm}$. Elution was carried out using a $0.05 \mathrm{M}$ Tris-HCl buffer $(\mathrm{pH} \mathrm{7.5)+}$ $0.2 \mathrm{M}-\mathrm{NaCl}$ as the eluant. Butanol was added to the solution in a concentration of $2 \%(\mathrm{v} / \mathrm{v})$. Filtration was done at $6^{\circ} \mathrm{C}$ and at a flow rate of $8 \mathrm{ml} / \mathrm{hr}$. Fractions of $2.5 \mathrm{ml}$ were collected in a fraction collector fitted with a special device (by Mr. L.-G. Falksveden, Department of Chemistry, National Bacteriological Laboratory, Stockholm) to enable constant volume fractions to be taken. The optical density of the fractions was determined at wavelengths $240 \mathrm{~m} \mu$ and $280 \mathrm{~m} \mu$ on a Beckman type DU spectrophotometer.

(B) Hydrolysis of haemoglobin. Haemoglobin medium was prepared in accordance with a modification to the original (1938) Anson method. Four $g$ bovine haemoglobin (enzyme substrate powder, Armour Pharmaceutical Company Ltd., Eastbourne, England) was mixed with $8 \mathrm{ml} 1 \mathrm{~N}-\mathrm{NaOH}, 36 \mathrm{~g}$ urea and $1 \mathrm{ml} 1 \%(\mathrm{w} / \mathrm{v})$ merthiolate. Distilled water was added to make $100 \mathrm{ml}$.

The haemoglobin solution was kept for 4-5 hrs. at room temperature and under frequent stirring. With all ingredients dissolved $\mathrm{pH}$ was adjusted to 7.5 by means of $2 \mathrm{~N}-\mathrm{HCl}$ and the solution was then stored at $-20^{\circ} \mathrm{C}$.

The determination of haemoglobin hydrolyzing activity was performed in a reaction solution made up of $0.3-1 \mathrm{ml}$ enzyme solution, $2 \mathrm{ml}$ buffer solution and $1 \mathrm{ml} 4 \%$ substrate solution. (Further details are to be found under Figures). Following incubation at $37^{\circ} \mathrm{C}$ the 
digestion was discontinued by addition of $5 \mathrm{ml} 0.3 \mathrm{M}$ trichloroacetic acid solution (TCA). The mixture was allowed to stand at room temperature for $1 \mathrm{hr}$. after which the precipitate was removed by filtration. The amount of TCA-soluble degradation products was determined by measuring the optical density of the TCA filtrate, using a Beckman, type DK-2 spectrophotometer operating at $280 \mathrm{~m} \mu$. The increase in optical density of the sample as compared to that of a blank has been used as a measure of the enzymatic activity of the fraction solution. The blank differed from the sample in that buffer solution mixed with enzyme solution was incubated separately, and the substrate solution, which had been incubated during the same length of time, was not incorporated until the TCA solution had been added. The hydrolytic effect of mycelial filtrate on haemoglobin is denominated 'haemoglobinase activity'.

The hydrolysis was performed at values of $\mathrm{pH}$ that were known (Rutquist 1969b) to yield optimum haemoglobin hydrolysis. The buffer solutions used in these experiments were all $0.45 \mathrm{M}$. A citrate buf-

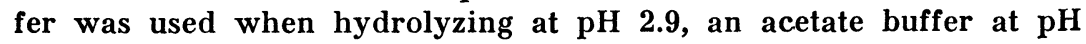
4.6 and a glycine buffer at $\mathrm{pH} 10$.

(C) Casein precipitation. The casein precipitating activity of various fractions obtained by gel filtration on Sephadex G-100 was investigated by means of casein agar that was prepared according to a method previously described (Rutqvist 1969a). The casein solution was thus obtained by dissolving 4 g sodium caseinate (Hammarsten grade, Hopkins \& Williams Ltd., Chadwell Heath, England) in $100 \mathrm{ml}$ distilled water, adjusting the $\mathrm{pH}$ to 7.5. The definite composition of the casein agar was as follows: $0.25 \%$ sodium caseinate, $1.5 \%$ Bacto-Agar Difco, $0.004 \mathrm{M}-\mathrm{MgCl}_{2}$, added as an $8 \%(\mathrm{w} / \mathrm{v})$ solution, and $0.01 \%(\mathrm{w} / \mathrm{v})$ merthiolate. After mixing the ingredients the $\mathrm{pH}$ was adjusted to 6.2 and the agar was poured into Petri dishes of $185 \mathrm{~mm}$ diameter to a depth of $2 \mathrm{~mm}$ and allowed to set. Following solidification, holes of $6 \mathrm{~mm}$ diameter were punched in the agar. Each hole was filled with $0.025 \mathrm{ml}$ fraction solution and the agar plates were incubated for $19 \mathrm{hrs}$. in a moist chamber at $37^{\circ} \mathrm{C}$. The precipitation zones occurring around the holes were then read and measured by means of millimetre sectional paper and a magnifier $(2.5 \times)$.

Determination of haemolytic activity.

The various Sephadex fractions were examined for haemolytic activity by mixing $0.5 \mathrm{ml}$ fraction solution with $0.5 \mathrm{ml}$ of a $2 \%$ suspension of sheep erythrocytes in $1 / 10 \mathrm{M}$ veronal buffer $(\mathrm{pH} 7)$. The mixture was incubated at $37^{\circ} \mathrm{C}$ for $30 \mathrm{~min}$. and at $20^{\circ} \mathrm{C}$ for an additional $90 \mathrm{~min}$. prior to reading.

\section{Determination of toxic activity}

The various Sephadex fractions were examined for toxic activity by intraperitoneal injections into groups of $2-5$ mice for each frac- 
tion. The mice (NMRI strain, Naval Medical Research Institute, Bethesda, Md., USA) weighed 16-18 $\mathrm{g}$ and were injected $0.5 \mathrm{ml}$ each. The animals were observed for a period of 10 days.

\section{Immuno-electrophoresis}

Immuno-electrophoretic investigations of dialyzed mycelial filtrate and of proteinase purified by gel filtration were performed by means of adapted microtechniques as described by Grabar \& Burtin (1964). The purified proteinase comprised the combined proteinasepositive fractions $185-248$ (cf. Fig. 4) obtained after gel filtration on Sephadex G-100 which, following dialysis, had been freeze-dried and subsequently dissolved in distilled water to yield the same drymatter content as the dialyzed filtrate.

The electrophoresis was carried out in a layer of buffered Noble agar about $1 \mathrm{~mm}$ thick (1 $\mathrm{g}$ Noble agar Difco $+75 \mathrm{ml}$ distilled water $+25 \mathrm{ml} 0.05 \mathrm{M}$ phosphate buffer, $\mathrm{pH} \mathrm{7)}$ on slides $(2.5 \times 7.5 \mathrm{~cm})$ that were arranged in $5.3 \times 26.6 \mathrm{~cm}$ frames. At the electrophoresis a $0.05 \mathrm{M}$ phosphate buffer $(\mathrm{pH} 7)$ was employed. The fractionation was performed in an electrophoresis apparatus (De Luxe Electrophoresis Chamber, Gelman Instrument Company, Ann Arbor, Mich., USA) at room temperature during $1 \mathrm{hr}$. at a current of about $10 \mathrm{mamp}$. per frame and at a potential gradient of about $10 \mathrm{v} / \mathrm{cm}$.

Following fractionation, antiserum was introduced into a trough cut out in the agar layer parallel to the fractionated antigens. The precipitation arcs thus produced were read after storing the slides for $24 \mathrm{hrs}$. in a moist chamber at room temperature.

\section{Dialysis}

The mycelial filtrate was dialyzed, unless otherwise stated, at room temperature against ordinary running tap water for $17 \mathrm{hrs}$. and against sterile distilled water for $2 \mathrm{hrs}$.

\section{pH determination}

All $\mathrm{pH}$ determinations were done by means of a glass electrode, using a $\mathrm{pH}$ meter of the type 28 made by Radiometer, Copenhagen, Denmark.

\section{Protein determination}

Determinations of nitrogen content in mycelial filtrate were carried out according to the micro-Kjeldahl technique. The factor, 6.25 was used in converting $\mathbf{N}$ content into protein content. In fractions collected after gel filtration the protein content was calculated after measuring the optical density at $260 \mathrm{~m} \mu$ and $280 \mathrm{~m} \mu$, using nomograms devised by Warburg \& Christian (1942). 

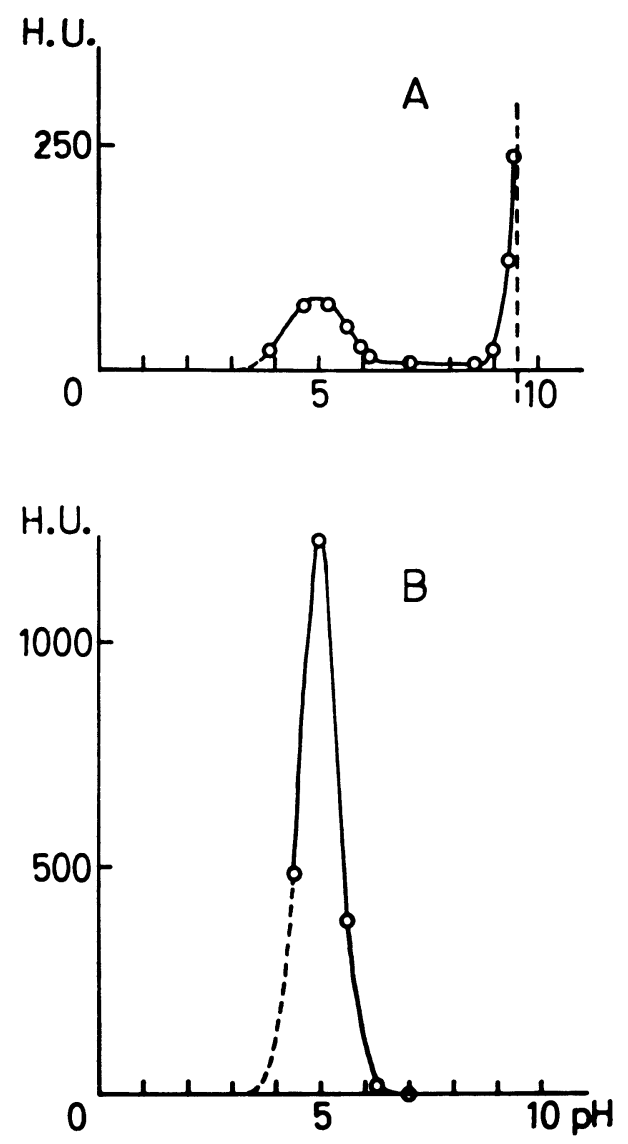

F ig u re 1. Influence of pH upon the hydrolysis of poly-L-lysine (A) and poly-L-glutamine (B) by mycelial filtrate from Aspergillus fumigatus strain 6869. H.U. = Hultin unit.

\section{EXPERIMENTS AND RESULTS}

\section{Hydrolysis of poly- $\alpha$-amino acids}

The effect of $\mathrm{pH}$ on the hydrolysis of poly-L-lysine and polyL-glutamine caused by crude filtrate of mycelial material from $\mathrm{AF}$, is illustrated in Fig. 1. Optimum activity against the 2 substrates occurred at $\mathrm{pH} 5$. A certain hydrolytic activity on polyL-lysine starting at $\mathrm{pH} 9$ could also be observed.

Fig. 2 illustrates fractionation by gel filtration of poly-L-glutamine after hydrolysis caused by dialyzed mycelial filtrate from AF. The absorption spectrum of the dialyzed filtrate per se at the same concentration as in the reaction mixture can be seen 


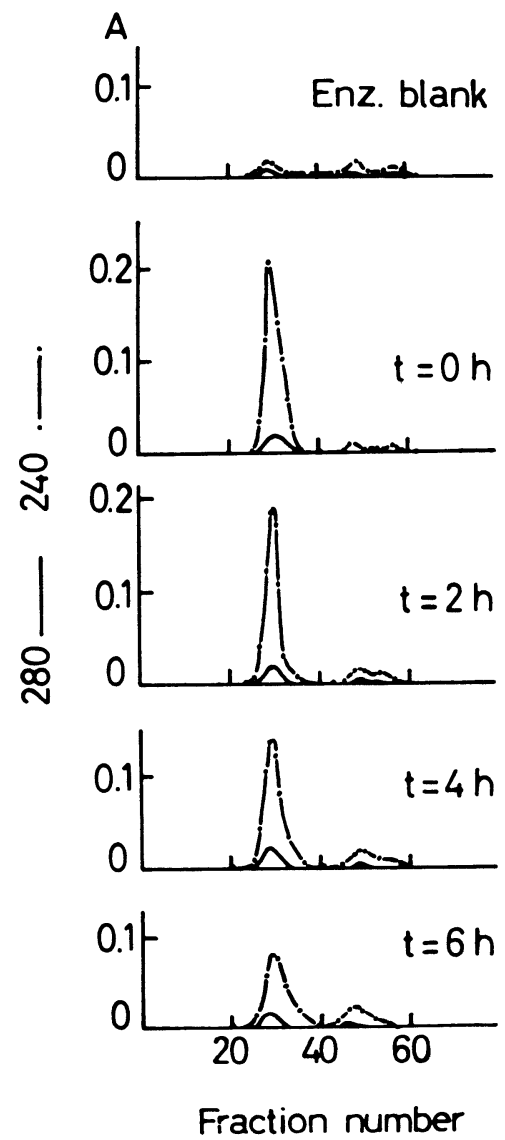

F i g u r e 2. Fractionation by gel filtration on Sephadex G-25 Fine of the products obtained when hydrozyling poly-L-glutamine by a mycelial filtrate from Aspergillus fumigatus strain 6869.

at the top of the figure. At this concentration the hydrolytic effect of the filtrate upon poly-L-glutamine was $2990 \mathrm{H}: \mathrm{U} . / \mathrm{ml}$. The substrate reduction following prolonged incubation and the increase in low-molecular degradation products are illustrated in the chromatograms.

\section{Fractionation of mycelial filtrate}

Gel filtration on Sephadex G-75 of mycelial filtrate that was first concentrated by means of Sephadex G-25 Coarse can be seen in Fig. 3. The u.v. absorbing material produced 5 peaks the first of which was elongated with diffuse borders. Most of the u.v. 
absorbing material was present in fractions $180-260$ where it produced a peak, which was divided at the end of the chromatogram into a large fourth peak and a smaller yet well defined fifth peak. The u.v. absorbing material present in the last 2 peaks, as distinguished from that of the previous peaks, showed greater absorption at $260 \mathrm{~m} \mu$ than at $280 \mathrm{~m} \mu$.

Proteolytic activity, using haemoglobin as substrate, at $\mathrm{pH}$ 2.9 , $\mathrm{pH} 4.6$ and $\mathrm{pH} 10$ occurred within the same area of the chromatogram, viz. in fractions $95-125$. In fractions $84-94$ there was also slight activity at $\mathrm{pH}$ 2.9. Maximum haemoglobinase activity at $\mathrm{pH} 2.9$ was found in fraction 111 , at $\mathrm{pH} 4.6$ in fractions 111 and 113, and at $\mathrm{pH} 10$ in fractions 113 and 114. Fractions 111, 113 and 114 all contained $120 \mu \mathrm{g}$ protein per ml (Table 1).

The haemoglobinase activity was as follows. At $\mathrm{pH} 2.9$ in fraction 111: $0.670 \mathrm{E}_{280} / 0.3 \mathrm{ml}$, corresponding to an activity of $18.600 \mathrm{E}_{280} / \mathrm{mg}$ protein. At $\mathrm{pH} 4.6$ in fraction $113: 0.880 \mathrm{E}_{280} / 0.3$ $\mathrm{ml}$, corresponding to an activity of $24.400 \mathrm{E}_{280} / \mathrm{mg}$ protein. At

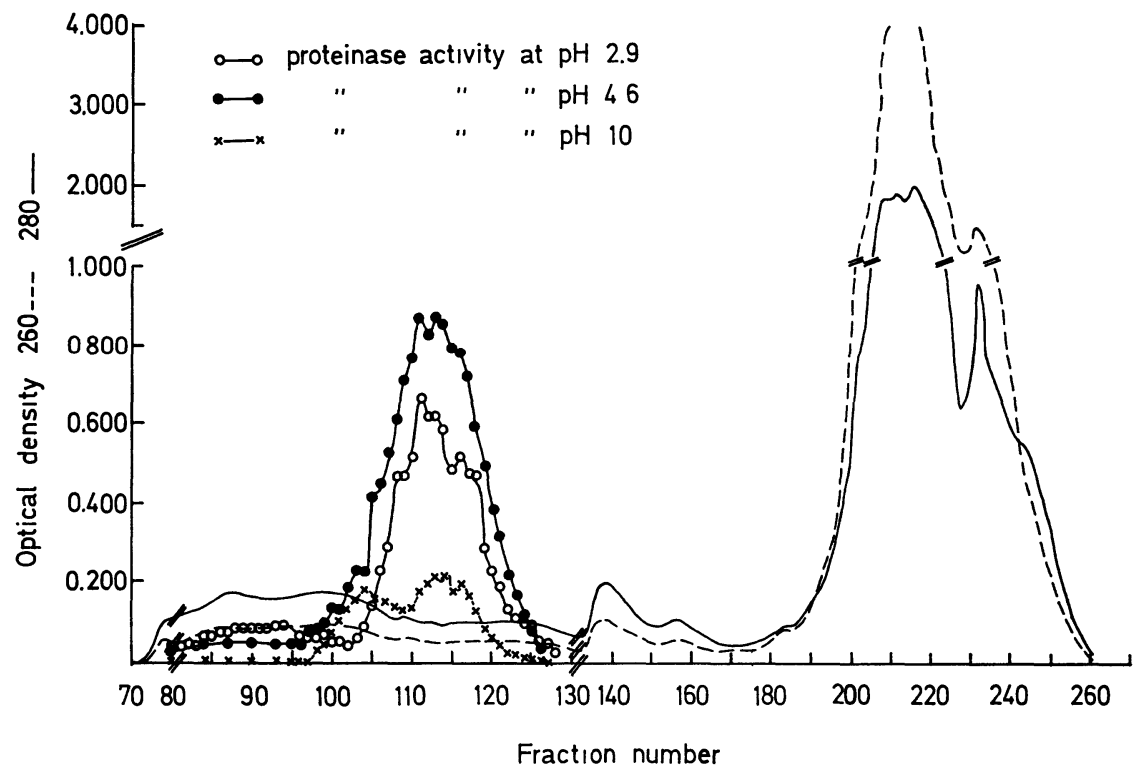

F i g u r e 3. Gel filtration on Sephadex G-75 of mycelial filtrate from Aspergillus fumigatus strain 6869. Basic procedure of haemoglobin hydrolysis: a reaction mixture of $0.3 \mathrm{ml}$ of fraction solution, $1 \mathrm{ml}$ of $4 \%$ haemoglobin solution and $2 \mathrm{ml}$ of buffer was incubated at $37^{\circ} \mathrm{C}$ for $4 \mathrm{hrs}$. 


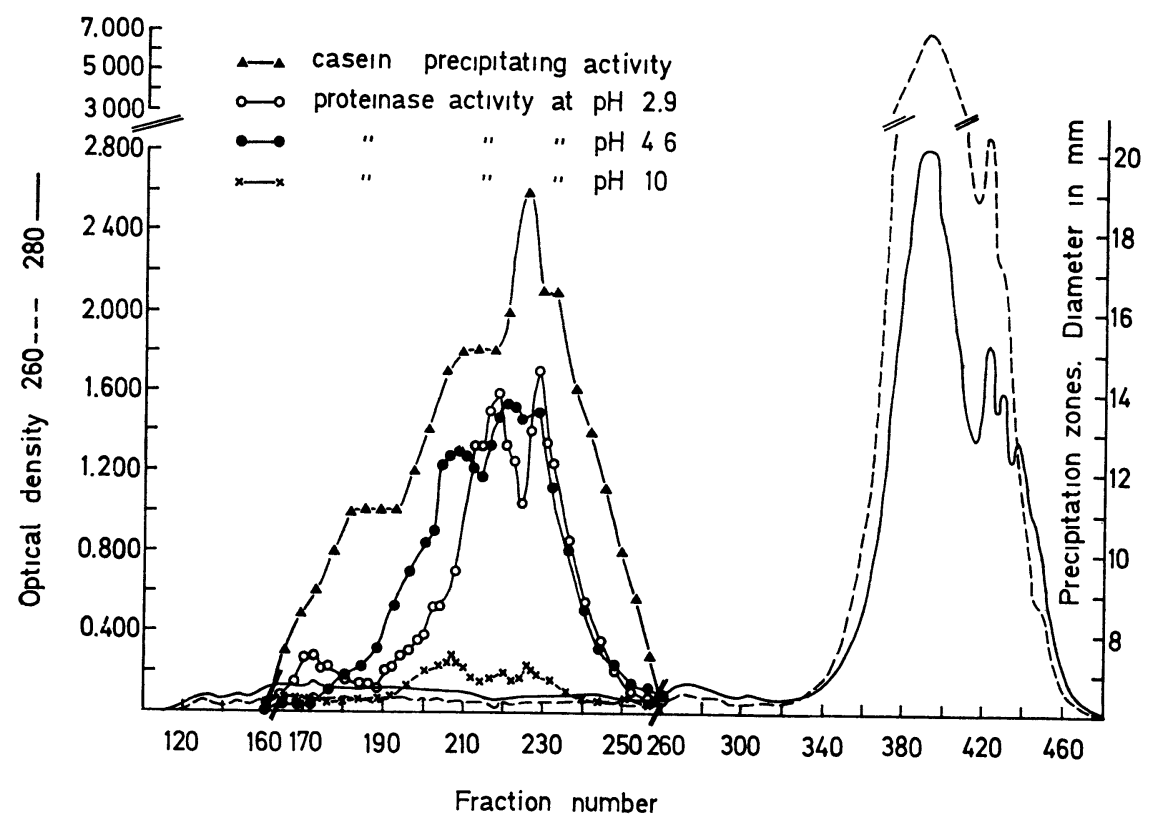

F i g u r e 4. Gel filtration on Sephadex G-100 of mycelial filtrate from Aspergillus fumigatus strain 6869. Basic procedure of haemoglobin hydrolysis: a reaction mixture of $1 \mathrm{ml}$ of fraction solution, $1 \mathrm{ml}$ of $4 \%$ haemoglobin solution and $2 \mathrm{ml}$ of buffer was incubated at $37^{\circ} \mathrm{C}$ for $4 \mathrm{hrs}$.

pH 10 in fraction 113: $0.210 \mathrm{E}_{280} / 0.3 \mathrm{ml}$, corresponding to 5.800 $\mathrm{E}_{280} / \mathrm{mg}$ protein. Under the same conditions the dialyzed filtrate, which contained $0.064 \%$ nitrogen, corresponding to $4 \mathrm{mg}$ protein per $\mathrm{ml}$, showed the following activity. At $\mathrm{pH} 2.9: 0.590 \mathrm{E}_{280}$, at $\mathrm{pH}$ 4.6: $1.330 \mathrm{E}_{280}$, and at $\mathrm{pH} 10: 0.320 \mathrm{E}_{280}$, in each case per $0.3 \mathrm{ml}$, corresponding to $0.490 \mathrm{E}_{280}$ at $\mathrm{pH} 2.9,1.100 \mathrm{E}_{280}$ at $\mathrm{pH} 4.6$ and $0.270 \mathrm{E}_{280}$ at $\mathrm{pH} 10$, in each case per mg protein. Hence, when using dialyzed mycelial filtrate as a standard, the purification factors were 38,22 and 22 at $\mathrm{pH}$ values $2.9,4.6$ and 10 , respectively.

In the chromatogram obtained after Sephadex G-75 filtration there was a certain tendency towards separation of the haemoglobinase activity curves at $\mathrm{pH} 2.9, \mathrm{pH} 4.6$ and $\mathrm{pH} 10$. For this reason mycelial filtrate was filtered on a Sephadex G-100 column in an attempt at separating from each other any possible activity peaks at the same $\mathrm{pH}$ value. The result is reproduced in Fig. 4.

As for the u.v. absorbing material the same basic picture was obtained as in the Sephadex G-75 filtration. The first peak was 
even less distinct, however, and the third peak was not quite so conspicuous as in the Sephadex G-75 filtration. At $280 \mathrm{~m} \mu$ the fifth peak was subdivided into 3 small peaks.

The haemoglobinase activity at pH 2.9 had been divided into 3 distinct activity peaks. The first, and smallest, peak occurred in fractions 164-186, with an activity maximum in fraction 172 . The other 2 activity peaks occurred in fractions $190-222$ and 226 - 256, with activity maxima in fractions 218 and 228, respectively.

A certain tendency towards separation was also noticed for the haemoglobinase activity at $\mathrm{pH} 4.6$ and $\mathrm{pH} 10$, but the activity peaks were less marked and displayed less clear-cut borders than the peaks for the haemoglobinase activity at pH 2.9. Haemoglobinase activity occurred in fractions $176-260$ and $184-252$ at pH 4.6 and pH 10, respectively. At pH 4.62 activity peaks were noticed. The first, and smaller, peak extended from fraction 176 to fraction 214 with an activity maximum in fraction 208 . The second, larger, activity peak, of a blunt shape, extended from fraction 214 to fraction 260, showing maximum activity in fraction 220. However, almost as strong activity was found in fractions 222, 224 and 228. The haemoglobinase activity occurring at pH 10 showed a division in 3 moderately marked peaks.

Table 1. Protein content of fractions obtained by gel filtration of mycelial filtrate on Sephadex columns. Aspergillus fumigatus strain 6869.

\begin{tabular}{llrlr}
\hline \multirow{2}{*}{$\begin{array}{c}\text { Protein } \\
\mu \mathrm{g} / \mathrm{ml}\end{array}$} & \multicolumn{5}{c}{ Fractions } \\
\cline { 2 - 5 } & \multicolumn{5}{c}{ Sephadex G-75 } & \multicolumn{3}{c}{ Sephadex G-100 } \\
\hline \multirow{2}{*}{$40-40$} & $74,171-173$ & 4 & $117-121$ & Number \\
$50-90$ & $75-76,128-133$, & 32 & $122-130,134-147$, & 106 \\
& $161-170,174-187$ & & $150-155,213-236$, & \\
& & & $246-260,291-302$, & \\
& & $304-329$ & \\
$100-140$ & $77-82,107-127,134$, & 47 & $131-133,148-149$, & 80 \\
& $146-160,188-191$ & & $156-162,170-171$, & \\
& & & $173-212,237-245$, & \\
& & $261-264,279-290,303$ & \\
$150-190$ & $83-97,100-106,135$, & 28 & $163-169,172,265-278$ & 22 \\
& $143-145,192-193$ & & & \\
$200-240$ & $98-99,136,142$ & 9 & & \\
\hline
\end{tabular}




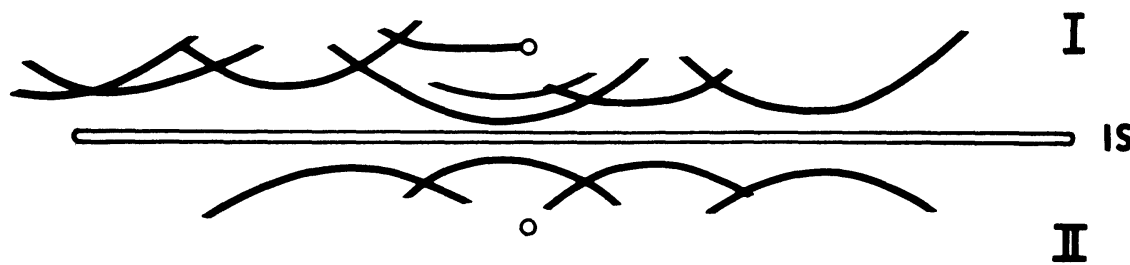

F ig u r e 5. Immuno-electrophoretic patterns of dialyzed mycelial filtrate and proteinase-positive fractions obtained by gel filtration of crude mycelial filtrate on Sephadex G-100 (fractions 185-248, Fig. 4). Aspergillus fumigatus strain 6869 .

$\mathrm{I}=$ Dialyzed mycelial filtrate.

II = Proteinase-positive fractions'obtained by filtration of mycelial filtrate on Sephadex G-100.

Casein precipitating activity was recorded in fractions 165257 (Fig. 4). Maximum activity occurred in fraction 225, where $0.025 \mathrm{ml}$ fraction solution in casein agar resulted in a precipitation zone of $19 \mathrm{~mm}$ diameter. There was no evident separation of the casein precipitating activity.

No haemolytic or toxic activity could be found in $0.5 \mathrm{ml}$ samples of fraction solution from any of the fractions obtained after gel filtration on Sephadex G-75 or G-100.

The protein contents of fractions $74-190$ from the gel filtration on Sephadex G-75 and of fractions 117-335 from the gel filtration on Sephadex G-100 are summarized in Table 1.

In fractions obtained after gel filtration on Sephadex G-75 the protein content was found to be $30-230 \mu \mathrm{g} / \mathrm{ml}$ and in fractions from gel filtration on Sephadex G-100, 10-170 $\mu \mathrm{g} / \mathrm{ml}$.

As can be seen in Fig. 5, dialyzed mycelial filtrate and proteinase purified by gel filtration on Sephadex G-100 produced, after electrophoretic separation, 8 and 4 precipitation arcs, respectively, with antiserum prepared against crude filtrate.

\section{DISCUSSION}

It has been shown by applying a viscosimetric procedure that mycelial filtrate from AF hydrolyzes poly-L-lysine and poly-Lglutamine. Earlier work by Martin \& Jönsson (1965) has shown that proteolytic enzyme recovered from broth used for AF cultivation hydrolyzes poly-L-glutamine at $\mathrm{pH} 4$ and poly-L-lysine at $\mathrm{pH} 10$. This was substantiated by a quantitative ninhydrin 
method devised by Matheson et al. (1961). The mycelial filtrate used in the present investigations proved to hydrolyze the 2 amino acids in the $\mathrm{pH}$ range, 4.6-5.3. As can be seen in Fig. 1 the filtrate showed stronger activity against poly-L-glutamine than against poly-L-lysine. An incipient activity against poly-Llysine was noted at $\mathrm{pH} 9 \mathrm{but}$, owing to spontaneous hydrolysis of the polyamino acid at $\mathrm{pH}$ values beyond 10 , it was impossible to trace the activity peak any further.

As in a previous investigation (Rutqvist 1969b) crude AF filtrate showed strong absorption at $280 \mathrm{~m} \mu$. For this reason dialyzed filtrate was used when investigating spectrophotometrically the degradation of poly-L-glutamine after gel filtration. The hydrolyzing effect of the dialyzed filtrate appeared as a distinct decrease in substrate associated with a simultaneous increase in the amount of low-molecular degradation products (Fig. 2).

The pronounced drop in viscosity that was observed when AF filtrate acted upon poly-L-glutamine or poly-L-lysine seems to indicate that the filtrate hydrolyzes central bonds in the molecule, i.e., that it acts as an endopeptidase.

Gel filtration of mycelial filtrate from AF on Sephadex G-75 or G-100 columns proved the filtrate to contain a considerable amount of low-molecular substances. The major part of the proteinase activity using haemoglobin as substrate at $\mathrm{pH}$ values 2.9, 4.6 and 10 appeared within the same area on the chromatograms. In gel filtration on Sephadex G-100, however, it was observed that the haemoglobinase activity reached a first peak, of moderate size, at $\mathrm{pH} 2.9$ and that this peak included also fractions of which no haemoglobinase activity could be determined at $\mathrm{pH}$ values 4.6 and 10 (Fig. 4). It is interesting to note that casein precipitating activity occurred also in fractions where haemoglobin hydrolyzing activity occurred only at $\mathrm{pH} 2.9$ but not at $\mathrm{pH} 4.6$ or 10 (Fig. 4). This seems to indicate that the casein precipitating activity is linked not only to the protein hydrolyzing activity with $\mathrm{pH} 6.2$ as the optimum, using casein as the substrate (cf. Rutqvist 1969 a), but also to the protein hydrolyzing activity at pH 2.9. Since it was possible to measure casein precipitating and protein hydrolyzing activity in identical fractions, following gel filtration on Sephadex G-100, the present investigations, like those of Sandvik (1962), have produced no evidence against the assumption that the casein precipitating 
enzyme is identical with the protein hydrolyzing enzyme. It should be remembered, however, that the enzymatic casein precipitation may probably express at the same time the activity of 2 or more protein hydrolyzing enzymes that may occur simultaneously in the test specimen. It is a confusing fact that the strongest casein precipitating activity, following filtration on Sephadex G-100, was found within an area of the chromatogram (fractions 221-229) where at the same time there was a marked inhibition of the haemoglobinase activity at $\mathrm{pH} 2.9$ (fractions $220-226$ ). There also seemed to be a certain inhibition of the haemoglobinase activity at $\mathrm{pH} 4.6$ and $\mathrm{pH} 10$ in this area of the chromatogram. It may be suggested as an explanation that the fractions in question may contain an inhibitor against haemoglobinase activity and that this inhibitor may be particularly active at $\mathrm{pH} 2.9$ without any apparent effect on the casein precipitating activity at $\mathrm{pH} 6.2$.

The above mentioned gel filtrations of mycelial filtrate from AF have not yielded any definite information enabling us to solve the question whether the haemoglobinase activity at $\mathrm{pH}$ values $2.9,4.6$ and 10 is actually associated with the activity of a single enzyme with several $\mathrm{pH}$ optima or a number of enzymes acting at different $\mathrm{pH}$ values. It might be possible to further elucidate this problem by means of isoelectric focussing. Following gel filtration on Sephadex G-100, however, the haemoglobinase activity has a peak at $\mathrm{pH} 2.9$, which includes fractions that do not seem to show any haemoglobinase activity at $\mathrm{pH} 4.6$ or $\mathrm{pH}$ 10. Apart from this the haemoglobinase activity curve for $\mathrm{pH} 2.9$ seems to differ slightly from the corresponding curves for $\mathrm{pH}$ 4.6 and $\mathrm{pH}$ 10. Also, the purification factor obtained after gel filtration on Sephadex G-75 in fractions with maximum haemoglobinase activity was greater at $\mathrm{pH} 2.9$ than the purification factors - both of the same size - associated with the haemoglobinase activity at $\mathrm{pH} 4.6$ and $\mathrm{pH} 10$. These conditions may suggest that the haemoglobinase activity at $\mathrm{pH} 2.9$ is caused by an enzyme, which is not identical with the enzyme(s) causing the haemoglobinase activity at $\mathrm{pH} 4.6$ and $\mathrm{pH} 10$. As for the haemoglobinase activity at the latter $2 \mathrm{pH}$ values the present investigation has revealed nothing that would be inconsistent with its being caused by one and the same enzyme in both cases. This would also be in line with the suggestion by Martin \& Jönsson that the protein hydrolyzing activity at $\mathrm{pH} 6.6$ and at $\mathrm{pH} 10$ with 
casein as substrate of broths employed for growing AF might well be caused by the same enzyme.

Judging from their position in the chromatogram following gel filtration on Sephadex G-100 the components producing the first activity peak at pH 2.9 (fractions 164-186) seem to have a molecular weight beyond 150,000 whereas the molecular weight of the components causing enzymatic activity at $\mathrm{pH} 2.9, \mathrm{pH} 4.6$ and $\mathrm{pH} 10$ in fractions $190-260$ seems to range between 100,000 and 30,000 . It would thus seem possible that the enzymatically active components encountered in the first activity peak at $\mathrm{pH}$ 2.9 may comprise a so-called multiple enzyme, i.e. aggregated molecular entities. It is also possible that the enzymatic activity occurring at $\mathrm{pH} 2.9, \mathrm{pH} 4.6$ and $\mathrm{pH} 10$ in fractions $190-260$ may have been caused, at least in part, by such multiple forms. Further, the presence of aggregated molecular entities may have been responsible for the separation into 2 distinct active peaks (fractions $190-222$ and $226-256$ ) that was observed in connection with the haemoglobinase activity at $\mathrm{pH}$ 2.9. The fact that the casein precipitating activity shows a very distinct activity peak in the area between the 2 peaks of haemoglobinase activity at $\mathrm{pH}$ 2.9 (fractions 220--226) suggests, however, that the separation of the haemoglobinase activity at that $\mathrm{pH}$ does not depend on the presence of multiple mulecular entities. As mentioned previously it would rather seem probable that the separation may be associated with an inhibiting agent present in the fractions in question (i.e. $220-226$ ), which counteracts the haemoglobinase activity, especially at $\mathrm{pH} 2.9$, but has no apparent effect on the casein precipitating activity at $\mathrm{pH} 6.2$.

Haemolysin and toxin present in mycelial filtrate from AF could not be recovered in any fraction following gel filtration on Sephadex G-75 and G-100 columns, respectively. The titres for haemolytic and toxic activity of the dialyzed filtrate were $2^{-10} \mathrm{ml}$ and $10^{-2.6} \mathrm{ml}$, respectively, the nitrogen content being $0.064 \%$, corresponding to a protein content of $4 \mathrm{mg} / \mathrm{ml}$. It is found under these conditions that a content of $40 \mu \mathrm{g}$ of protein per $\mathrm{ml}$ will yield $2 \mathrm{MLD}_{50}$ of toxin per $0.5 \mathrm{ml}$ filtrate and that $10 \mu \mathrm{g}$ of protein per $\mathrm{ml}$ will yield $>1 \mathrm{HU}$ per $0.5 \mathrm{ml}$ filtrate. As can be seen from Table 1 most of the fractions showing a stronger absorption at $280 \mathrm{~m} \mu$ than at $260 \mathrm{~m} \mu$ contain more than $40 \mu \mathrm{g}$ protein per $\mathrm{ml}$. Provided that the haemolysin (and toxin) retains unchanged its relation to the protein content after gel filtration, 
these activities, and the haemolytic activity in particular, should have been recovered in $0.5 \mathrm{ml}$ fraction solution. After the gel filtration there should also have been a certain purification effect, resulting in stronger activity per mg protein than could actually be found in the dialyzed filtrate. Hence, it is not very probable that haemolytic or toxic activity could have escaped discovery in these fractions, owing to the protein concentration being too low in the fractions. Fractions characterized by strong absorption, stronger at $260 \mathrm{~m} \mu$ than at 280 , probably contain the greater part of the low-molecular substances that disappear in ordinary dialysis and thus do not show any relationship to the haemolytic or toxic activity (cf. Rutqvist 1969 a). No haemolytic or toxic activity was expected in these fractions, nor could any such activity be established in samples of $0.5 \mathrm{ml}$ fraction solution from any of the fractions. The reason why no haemolysin or toxin could be found after fractionating the mycelial filtrate remains a matter of speculation. One explanation may be that activating substances necessary for haemolytic and toxic activity have simply been separated off during fractionation. There is also a slight possibility of the haemolysin and the toxin being adsorbed by the Sephadex gel despite the comparatively high concentration of the eluant. A third possibility, and perhaps one more probable than the other two, would be that the haemolysin or toxin may have lost its stability and become inactive, following purification. It should be mentioned here that Wynston \& Tilden (1963) seem to have been unsuccessful in recovering haemolysin or toxin from mycelial filtrate of AF after chromatography on a Duolite CS-101 column. Both haemolysin and toxin were found, however, in fractions obtained after chromatography on DEAE cellulose columns (Rau et al. 1961, Wynston \& Tilden). The fractions with haemolytic and toxic activity in these cases seem to have been less pure and have probably contained a considerably higher percentage of protein than the fractions obtained during our gel filtration, which may have had a stabilizing effect on the haemolysin and toxin.

Biguet et al. (1965) state that cellular antigen from AF produces 16 precipitation arcs with homologous rabbit antiserum. The number of arcs shows certain variations, however, depending on the length of time during which the mycelial material used for preparing the cellular antigen has been grown (cf. Biguet et al. 1964). It has been the sole object of the immuno- 
electrophoretic investigation reported by the authors in the present paper to study (a) how many precipitating antigens that could be found in the protein hydrolyzing fractions obtained after gel filtration on Sephadex G-100 and (b) the degree of purification that could be achieved as compared to dialyzed mycelial filtrate. It should be pointed out in this connection that the fractions forming the first small activity peak at $\mathrm{pH} 2.9$ after gel filtration have not been included among the fractions investigated.

Our investigation shows that, when using antiserum to a crude filtrate from a homologous AF strain, the purified proteinase-positive fractions with protein hydrolyzing activity at $\mathrm{pH} 2.9$, pH 4.6 and $\mathrm{pH} 10$ contained 4 precipitating antigens whereas the dialyzed filtrate contained 8 such antigens.

\section{REFERENCES}

Anson, M. L.: The estimation of pepsin, trypsin, papain and cathepsin with haemoglobin. J. gen. Physiol. 1938, 22, 79-89.

Biguet, J., P. Tran Van Ky, S. Andrieu \& J. Fruit: Analyse immunoélectrophorétique d'extraits cellulaires et de milieux de culture d'Aspergillus fumigatus par des immunsérums expérimenteus et des sérums de malades atteints d'Aspergillome bronchopulmonaire. (Immunoelectrophoretic analysis of cell extracts and culture media of Aspergillus fumigatus by means of experimental sera and of sera of patients suffering from bronchopulmonary aspergillosis). Ann. Inst. Pasteur 1964, 106, 72-97.

Biguet, J., P. Tran Van Ky, S. Andrieu \& J. Fruit: Analyse immunoélectrophorétique des antigènes fongigues et systématique des champignons. Répercussions pratiques sur le diagnostic des mycoses. (Immunoelectrophoretic analysis of the fungal antigens and the taxonomy of the fungi. Practical bearings on the diagnosis of the mycoses). Mycopathologia (Den Haag) 1965, $26,241-256$.

Grabar, P. \& P. Burtin: Immuno-Elektroforetische Analyse. (Immunoelectrophoretic analysis). Elsevier Publishing Company, Amsterdam, London, New York 1964.

Hultin, E.: A viscosimetrical method for the determination of enzymatic activity. Svensk kem. T. 1946, 58, 281-285.

Hultin, E.: Über die viscosimetrische Bestimmung von proteolytischen Enzymen. (Viscosimetric determination of proteolytic enzymes). Svensk kem. T. 1948, 60, 40-48.

Hultin, E. \& G. Lundblad: Viscosimetric determination of the "Michaelis constant" for proteolytic enzymes and its use for the determination of reaction mechanisms. Acta chem. scand. 1955, 9, $1610-1619$. 
Hultin, E. \& I. Wanntorp: Viscosimetric determination of cellulase activity in the mechanism and equilibrium constant for cellulase stabilization with calcium. Acta chem. scand. 1966, 20, $2667-2677$.

Lundblad, G.: Proteolytic activity and trypsin inhibiting ability of serum fractions obtained chromatographically on anionexchange Sephadex. Acta chem. scand. 1962, 16, 975-982.

Lundblad, G. \& E. Hultin: Human serum lysozyme (Muramidase). 1. Viscosimetric determination with glycol chitin and purification by selective adsorption. Scand. J. clin. Lab. Invest. 1966, 18, 201-208.

Lundblad, G. \& B. Johansson: The characterization of proteolytic enzymes with synthetic poly- $\alpha$-amino acids. Acta chem. scand. $1968,22,662-674$.

Martin, S. M. \& A. G. Jönsson: An extracellular protease from Aspergillus fumigatus. Canad. J. Biochem. 1965, 43, 1745-1753.

Matheson, A. T., E. Tigane \& C. S. Hanes: Quantitative chromatographic methods. Part 5. An improved ninhydrin-hydrindantin reagent. Canad. J. Biochem. 1961, 39, 417-425.

Rau, E., E. B. Tilden \& V. L. Koenig: Partial purification and characterization of the endotoxin from Aspergillus fumigatus. Mycophatologia (Den Haag) 1961, 15, 347-358.

Rutqvist, L.: Studies on Aspergillus fumigatus; toxin production of different strains and serological comparison of the strains. Acta vet. scand. $1965,6,224-233$.

Rutqvist, L.: Studies on Aspergillus fumigatus; stability of haemolysin and toxin in crude filtrate. Acta vet. scand. 1968, 9, 350-363.

Rutqvist, L.: Studies on Aspergillus fumigatus; casein precipitating and proteolytic effects of mycelial filtrate. Acta vet. scand. 1969 a, $10,18-35$.

Rutqvist, L.: Studies on Aspergillus fumigatus; properties of intracellular proteinase. Acta vet. scand. $1969 \mathrm{~b}, 10,234-254$.

Sandvik, O.: Studies on casein precipitating enzymes of aerobic and facultatively anaerobic bacteria. Thesis, Oslo 1962.

Söder, P. ö.: Proteolytic activity of dental plaque material. Part IV. Lysis of hemoglobin, amino-acid esters and synthetic poly- $\alpha$ amino acid. Odont. T. 1967, 75, 237-252.

Warburg, O. \& W. Christian: Isolierung und Kristallisation des Gärungsferments Enolase. (Isolation and crystallization of the ferment enolase). Biochem. Z. 1942, 310, 384-421.

Wynston, L. K. \& E. B. Tilden: Chromatographic fractionation of Aspergillus endotoxins. Mycopathologia (Den Haag) 1963, 20, $272-283$.

\section{SUMMARY}

Mycelial filtrates from Aspergillus fumigatus (AF), shown to possess haemolytic, toxic, casein precipitating, and protein hydrolyzing activity, hydrolyzed poly-L-lysine and poly-L-glutamine in the $\mathrm{pH}$ range 4.6-5.3. Incipient activity against poly-L-lysin was observed 
at $\mathrm{pH}$ 9. Owing to spontaneous hydrolysis of the polyamino acid at $\mathrm{pH}>10$, no activity optimum could be traced.

Gel filtration of mycelial filtrate on Sephadex G-75 or G-100 columns offered no definite information whether the protein hydrolyzing activity, using haemoglobin as substrate, at the optimum $\mathrm{pH}$ values, $2.9,4.6$ and 10 , shows the activity of a single enzyme with more than $1 \mathrm{pH}$ optimum or of more than 1 enzyme active at different $\mathrm{pH}$ values. Certain results of the investigations seem to indicate that the protein hydrolyzing activity at $\mathrm{pH} 2.9$ was not caused by enzymes identical with the enzyme(s) causing the protein hydrolyzing activity at $\mathrm{pH}$ 4.6 or $\mathrm{pH} 10$.

Casein precipitating and protein hydrolyzing activity occurred, following gel filtration on a Sephadex G-100 column, in identical fractions whereas neither haemolysin nor toxin could be found in samples of $0.5 \mathrm{ml}$ fraction solution from any of the fractions after filtration on Sephadex G-75 or G-100 columns.

By using antiserum to a crude filtrate from a homologous AF strain it could be shown, applying immuno-electrophoresis, that dialyzed mycelial filtrate contained 8 precipitating antigens whereas proteinase purified by gel filtration and displaying protein hydrolyzing activity at $\mathrm{pH} 2.9, \mathrm{pH} 4.6$ and $\mathrm{pH} 10$ contained 4 such antigens.

\section{ZUSAMMENFASSUNG}

Studien über Aspergillus fumigatus; Hydrolyse von poly- $\alpha$-Aminosäuren durch Myzelienfiltrat sowie chromatographische Fraktionierung des Filtrates.

Myzelienfiltrate von Aspergillus fumigatus (AF), die hämolytische, toxische, Kasein-präzipitierende und Protein-hydrolysierende Aktivität zeigten, hydrolysierten poly-L-lysin und poly-L-glutamin in dem pH-Gebiet von 4,6-5,3. Der erneute Beginn einer Aktivität gegen poly-L-lysin konnte bei pH 9 beobachtet werden. Auf Grund der spontanen Hydrolyse der Aminosäure bei höheren pH-Werten als 10 konnte das Aktivitätsoptimum nicht bestimmt werden.

Die Gelfiltration von Myzelienfiltraten mit Sephadex G-75 bzw. G-100 Kolonnen gab keinen sicheren Hinweis darauf in wieweit die Protein-hydrolysierende Aktivität mit Hämoglobin als Nährboden bei den optimalen pH-Werten 2,9, 4,6 bzw. 10 die Aktivität von nur einem Enzym mit mehreren pH-Optima oder die mehrerer bei verschiedenen pH-Werten aktiven Enzymen wiederspiegelt. Gewisse Untersuchungsresultate deuten jedoch darauf hin, dass die Protein-hydrolysierende Aktivität bei $\mathrm{pH} 2,9$ nicht von einem Enzym verursacht wird, dass mit dem oder den Enzymen identisch ist, die die Protein-hydrolysierende Aktivität bei $\mathrm{pH} \mathrm{4,6} \mathrm{bzw.} \mathrm{pH} 10$ bewirken.

Kasein-präzipitierende und Protein-hydrolysierende Aktivität trat nach der Gelfiltration mit Sephadex G-100 Kolonnen in identischen Fraktionen auf, während weder Hämolysin noch Toxin in 0,5 ml Fraktionslösung nach Filtrierung durch Sephadex G-75 bzw. Sephadex G100 Kolonnen in keiner der Fraktionen nachgewiesen werden konn- 
ten. Die Möglichkeit, dass Kasein-präzipitierende und Protein-hydrolysierende Aktivität von identischen Enzymen hervorgerufen werden kann, sowie die Ursachen, dass weder Hämolysin noch Toxin nach den Gelfiltrationen nachgewiesen werden konnten, werden besprochen.

Unter Anwendung eines Immunserums gegen Rohfiltrat von einem homologen AF-Stamm wurde in Immunoelektrophorese nachgewiesen, dass dialysierte Myzelienfiltrate 8 präzipitierende Antigene enthalten, während durch Gelfiltration gereinigte Proteinase mit Protein-hydrolysierender Aktivität bei pH 2,9, pH 4,6 bzw. pH 10, 4 präzipitierende Antigene enthält.

\section{SAMMANFATTNING}

Studier av Aspergillus fumigatus; hydrolys av poly- $\alpha$-aminosyror förorsakad av myceliefiltrat och kromatografisk fraktionering av filtratet.

Myceliefiltrat från Aspergillus fumigatus (AF), som visats ha hämolytisk, toxisk, kaseinprecipiterande och proteinhydrolyserande aktivitet hydrolyserade poly-L-lysin och poly-L-glutamin i $\mathrm{pH}$-intervallet 4,6-5,3. En begynnande aktivitet mot poly-L-lysin kunde iakttagas vid $\mathrm{pH} 9$. På grund av aminosyrans spontanhydrolys vid $\mathrm{pH}$ värden högre än $\mathrm{pH} 10$ kunde aktivitetsoptimum ej bestämmas.

Gelfiltrering av myceliefiltratet på Sephadex G-75 respektive G100 kolonner gav ingen säker upplysning om huruvida den proteinhydrolyserande aktiviteten med hämoglobin som substrat vid respektive optimala pH-värden $2,9,4,6$ och 10 reflekterar aktiviteten hos endast ett enzym med flera pH-optima eller flera enzym aktiva vid olika pH-värden. Vissa undersökningsresultat antydde dock att den proteinhydrolyserande aktiviteten vid $\mathrm{pH} 2,9$ icke förorsakades av enzym identisk med det eller de enzym, som förorsakade den proteinhydrolyserande aktiviteten vid respektive $\mathrm{pH} 4,6$ och $\mathrm{pH} 10$.

Kaseinprecipiterande och proteinhydrolyserande aktivitet uppträdde efter gelfiltreringen på Sephadex G-100 kolonn i identiska fraktioner medan varken hämolysin eller toxin kunde påvisas i 0,5 ml fraktionslösning från någon av fraktionerna efter filtrering på Sephadex G-75 respektive Sephadex G-100 kolonner. Möjligheterna för att kaseinprecipiterande och proteinhydrolyserande aktivitet förorsakas av identiskt enzym liksom orsakerna till att hämolysin respektive toxin ej kunde påvisas efter gelfiltrationerna diskuteras.

Med användande av immunserum mot råfiltrat från homolog $\mathrm{AF}$ stam kunde vid immunelektrofores visas att dialyserat myceliefiltrat innehöll 8 medan genom gelfiltrering renat proteinas med proteinhydrolyserande aktivitet vid respektive $\mathrm{pH} 2,9, \mathrm{pH} 4,6$ och $\mathrm{pH} 10$ innehöll 4 precipiterande antigen.

(Received January 13, 1969). 